JURNAL NOMINAL / VOLUME VII NOMOR 1 / TAHUN 2018

\title{
PENGARUH KOMPETENSI, INDEPENDENSI DAN MORAL REASONING AUDITOR TERHADAP KUALITAS AUDIT (Studi Pada Kantor Inspektorat Daerah Di Propinsi Daerah Istimewa Yogyakarta)
}

\author{
EFFECT OF COMPETENCE, INDEPENDENCE AND AUDITOR MORAL \\ REASONING TOWARDS AUDIT QUALITY (Study on Regional Inspectorate Office in \\ Special Region of Yogyakarta)
}

\author{
Hamzah Faid Falatah \\ Prodi Akuntansi Universitas Negeri Yogyakarta \\ falatahfaid@gmail.com \\ Sukirno \\ Staf Pengajar Jurusan Pendidikan Akuntansi Universitas Negeri Yogyakarta
}

\begin{abstract}
Abstrak: Pengaruh Kompetensi, Independensi dan Moral Reasoning Auditor terhadap Kualitas Audit (Studi Pada Kantor Inspektorat Daerah di Propinsi Daerah Istimewa Yogyakarta)

Penelitian ini bertujuan untuk mengetahui pengaruh: (1) Kompetensi Auditor terhadap Kualitas Audit, (2) Independensi Auditor terhadap Kualitas Audit, (3) Moral Reasoning Auditor terhadap Kualitas Audit, dan (4) Pengaruh Kompetensi, Independensi dan Moral Reasoning Auditor secara bersama-sama (simultan) terhadap Kualitas Audit. Populasi penelitian ini sebanyak 116 auditor Kantor Inspektorat Daerah Di Propinsi Daerah Istimewa Yogyakarta. Teknik analisis data menggunakan analisis statistik deskriptif, uji prasyarat analisis, analisis regresi linier sederhana, dan analisis regresi linier berganda.Hasil penelitian menunjukkan: (1) Terdapat pengaruh positif dan signifikan Kompetensi Auditor terhadap Kualitas Audit, (2) Terdapat pengaruh positif dan signifikan Independensi Auditor terhadap Kualitas Audit, (3) Terdapat pengaruh positif dan signifikan Moral Reasoning Auditor terhadap Kualitas Audit, dan (4) Terdapat pengaruh positif dan signifikan Kompetensi, Independensi dan Moral Reasoning Auditor secara bersama-sama (simultan) terhadap Kualitas Audit.
\end{abstract}

Kata kunci: Kualitas Audit, Kompetensi Auditor, Independensi Auditor, Moral Reasoning Auditor.

Abstract: Effect of Competence, Independence and Auditor Moral Reasoning towards Audit Quality (Study on Regional Inspectorate Office in Special Region of Yogyakarta)

This study aimed to determine the effect of: (1) Auditor Competence toward Audit Quality, (2) Auditor Independece toward Audit Quality, (3) Auditor Moral Reasoning toward Audit Quality, and (4) Competence, Independece and Auditor Moral Reasoning which work simultaneously toward Audit Quality. The population of this study were 116 auditors at Regional Inspectorate Office in Special Region of Yogyakarta. Data analysis technique used descriptive statistical analysis, test requirements analysis, simple linear regression analysis, and double linear regression analysis.The results showed: (1) There are positive and significant effects in Auditor Competence toward Audit Quality, (2) There are positive and significant effects in Auditor Independence toward Audit Quality, (3) There are positive and significant effects in Auditor Moral Reasoning toward Audit Quality, and (4) There are positive and significant effects in Competence, Independece and Auditor Moral Reasoning which work simultaneously toward Audit Quality.

Keywords: Audit Quality, Auditor Competence, Auditor Independence, Auditor Moral Reasoning. 


\section{JURNAL NOMINAL / VOLUME VII NOMOR 1 / TAHUN 2018}

\section{PENDAHULUAN}

Masyarakat Ekonomi Korupsi, kolusi dan nepotisme $(\mathrm{KKN})$ merupakan suatu tindakan yang dilakukan oleh seseorang atau kelompok dengan tujuan untuk memperoleh kekayaan pribadi. KKN termasuk dalam suatu tindakan yang amoral yang dilakukan seseorang. Tindakan ini termasuk tindakan yang melanggar hukum. Di Indonesia tindakan amoral seperti ini masih banyak terjadi di setiap instansi pemerintah. Menurut Lembaga Transparency International (TI) yang merilis data tentang indeks persepsi korupsi menempatkan Indonesia pada peringkat 88 di dunia (Presetiyo, 2016). Hal ini memberikan suatu gambaran pentingnya menjaga kualitas pertanggungjawaban pemerintah kepada publik.

Mempertahankan kepercayaan publik terhadap pertanggungjawaban pemerintah saat ini merupakan suatu hal yang sulit dilakukan. Publik terbiasa melihat dan mendengar kasus-kasus tindakan amoral khususnya korupsi yang telah dipublikasikan oleh media. Masyarakat merasa sulit untuk percaya terhadap laporan pertanggungjawaban pemerintah. Laporan pertanggungjawaban tersebut dinilai belum memiliki kualitas yang baik.

Laporan pertanggungjawaban permerintah yang baik harus diaudit sesuai standar audit dan dilaksanakan oleh pihak yang independen dan berkompeten agar memperoleh hasil audit yang berkualitas. Audit merupakan suatu proses sistematis dan mengevaluasi bukti yang berhubungan dengan asersi tentang tindakan-tindakan dan kejadian-kejadian ekonomi secara objektif untuk menentukan tingkat kepatuhan antara asersi tersebut dengan kriteria yang telah ditetapkan dan mengomunikasikan hasilnya kepada pihakpihak yang berkepentingan (Jusup, 2014: 10). Di dalam sektor pemerintah terdapat aparat yang bertugas untuk melakukan audit atas laporan pertanggungjawaban atau laporan keuangan pemerintah baik secara internal maupun eksternal. Secara internal audit pemerintah dilakukan oleh Aparatur Pengawas Intern Pemerintah (APIP) dan Badan Pengawas Keuangan (BPK) secara eksternal. Aparatur negara ini bertugas untuk melakukan pengawasan agar tidak terjadi korupsi, kolusi dan nepotisme yang ada di badan pemerintahan.

Menurut Peraturan Pemerintah No. 60 Tahun 2008 tentang sistem pengendalian intern pemerintah, pengendalian tersebut dilakukan oleh Aparat Pengawasan Intern Pemerintah (APIP), yaitu Badan Pengawasan Keuangan dan Pembangunan (BPKP); Inspektorat Jenderal; Inspektorat Provinsi; dan Inspektorat Kabupaten/Kota. Pada lingkup pemerintah daerah, Inspektorat daerah kabupaten/kota merupakan garda terdepan dalam mencegah maupun menanggulangi terjadinya praktik 


\section{JURNAL NOMINAL / VOLUME VII NOMOR 1 / TAHUN 2018}

KKN. Audit yang berkualitas sangat diperlukan untuk menjaga kepercayaan publik.

Hasil audit yang berkualitas merupakan sebuah tujuan yang harus dicapai oleh APIP. Kualitas Audit adalah pemeriksaan yang sistematik dan independen untuk menentuan apakah kualitas aktivitas dan pencapaian hasil sesuai dengan rencana yang sudah dirancang serta dapat dilaksanakan secara efektif dalam pencapaian tujuan (Bastian, 2014: 270). Kualitas Audit merupakan suatu tindakan auditor dalam melaksanakan audit berdasarkan standar auditing yang telah ditetapkan dan melaporkan hasil auditnya berdasarkan kecukupan bukti yang ada kepada pihak yang memiliki kepentingan. Terdapat beberapa faktor yang mempengaruhi Kualitas Audit, yaitu Kompetensi, Independensi dan Moral Reasoning Auditor.

\section{Kompetensi Auditor adalah} kepandaian khusus yang dimiliki oleh seorang pemeriksa yang diakui mampu menggunakan teori dan praktik untuk melaksanakan profesinya (Ulum, 2012: 95). Keahlian yang dimiliki seorang auditor harus dijaga dan ditingkatkan agar hasil auditnya berkualitas. Namun, fenomena yang terjadi belakangan ini menjadi menjadi sorotan publik karena kompetensi auditor yang rendah, misalnya berdasarkan hasil pemeriksaan BPK terhadap 191 LKPD telah ditemukan 3.051 kasus senilai Rp 9,93 triliun akibat ketidakpatuhan perundangundangan yang berlaku dan 556 kasus telah merugikan negara senilai Rp 310,86 miliar. Berdasarkan laporan BPK semester II menyimpulkan perkembangan opini laporan keuangan pemerintah daerah semakin memburuk kualitasnya, serta banyaknya LKPD yang dinyatakan disclaimer (Nabhani, 2009). Hal ini mengindikasikan bahwa kompetensi yang dimiliki auditor inspektorat masil tergolong rendah.

Selain kompetensi, seorang auditor juga harus memiliki independensi. Independensi Auditor adalah suatu pandangan yang tidak berprasangka (unbiased viewpoint) saat melaksanakan pengujian, penilaian terhadap hasil penyajian laporan audit (Munawir, 1999: 71). Seorang auditor harus memiliki sikap independen agar audit yang dihasilkan berkualitas. Namun banyak kasus yang terjadi berkaitan dengan rendahnya kualitas audit akibat sikap auditor yang tidak independen. Misalnya kasus suap auditor BPK atas pemberian penilaian wajar tanpa pengecualian (WTP) atas laporan keuangan Pemkot Bekasi (Ferdinan, 2010).

Faktor lain yang harus dimiliki seorang auditor selain Kompetensi dan Independensi agar menghasilkan audit yang berkualitas, yaitu Moral Reasoning. Moral Reasoning adalah suatu alasan sebagai dasar seseorang untuk mengambil tindakan atau alasan sebagai dasar seseorang untuk 


\section{JURNAL NOMINAL / VOLUME VII NOMOR 1 / TAHUN 2018}

mengkritik atau membenarkan sebuah perbuatan (Gaffikin \& Lindawati, 2012). Seorang auditor harus menentukan hasil audit apakah wajar tau tidak berdasarkan kecukupan bukti yang ada agar hasil auditnya berkualitas. Namun belakangan ini berbagai kasus korupsi yang menjerat kepala daerah mulai muncul ke publik, hal ini menjadi bukti tidak optimalnya peran inspektorat dalam melakukan pengawasannya (Angga, 2017). Contoh kasusnya yaitu kasus yang menimpa mantan Bupati Bantul yang melakukan penyelewengan penggunaan anggaran terkait dengan administrasi dana hibah Persiba sebesar Rp 12,5 milyar yang berasal dari dana APBD sebesar Rp 8 miliar dan APBD Perubahan pada 2001 sebesar Rp 4,5 miliar (Pratama, 2014). Auditor inspektorat tidak dapat untuk mengungkap kasus tersebut karena statusnya sebagai Pegawai Negeri Sipil (PNS) terancam, untuk mencari posisi aman, auditor memilih untuk tidak mengungkapnya demi keuntungan pribadi.

Berdasarkan latar belakang yang telah dijelaskan di atas, penulis tertarik untuk melakukan penelitian dengan judul "Pengaruh Kompetensi, Independensi dan Moral Reasoning Auditor terhadap Kualitas Audit (Studi Pada Kantor Inspektorat Daerah Di Propinsi Daerah Istimewa Yogyakarta)."

\section{METODE PENELITIAN}

Penelitian ini termasuk penelitian kuantitatif sebab menggunakan data berupa angka-angka dan analisis data dilakukan dengan menggunakan statistik. Berdasarkan karakteristiknya, penelitian ini tergolong sebagai penelitian kausal komparatif. Artinya, penelitian kausal komparatif merupakan tipe penelitian dengan karakteristik masalah berupa hubungan sebab akibat antara dua variabel atau lebih, peneliti mengidentifikasi faktor sebagai variabel yang dipengaruhi (variabel dependen) dan melakukan penyelidikan terhadap variabel yang mempengaruhi (variabel independen) (Indrianto dan Supomo 2002: 27). Dalam penelitian ini terdapat 3 variabel independen yaitu Kompetensi Auditor, Independensi Auditor dan Moral Reasoning Auditor, sedangkan variabel dependen berupa Kualitas Audit.

\section{Instrumen Penelitian}

Instrumen penelitian adalah suatu alat yang digunakan oleh peneliti untuk mengukur fenomena yang diamati (Sugiyono, 2011: 102). Instrumen yang digunakan adalah kuesioner yang item-item pertanyaannya diadopsi dan dimodifikasi dari penelitian-penelitian terdahulu. Dalam penelitian ini skala pengukuran Likert. Setiap item pernyataan diukur dengan menggunakan Skala Likert mulai dari skor 1 sampai 4. Skor 1 menunjukkan Sangat Tidak Setuju (STS), Skor 2 menunjukkan 


\section{JURNAL NOMINAL / VOLUME VII NOMOR 1 / TAHUN 2018}

Tidak Setuju (TS), skor 3 menunjukkan Setuju (S), skor 4 menunjukkan Sangat Setuju (SS).

Instrumen yang digunakan untuk mengukur variabel Kompetensi Auditor mengadopsi dari instrumen yang digunakan oleh Harahap (2016), variabel Independensi Auditor mengadopsi dari instrumen yang digunakan oleh Harahap (2016), variabel Moral Reasoning Auditor mengadopsi instrumen yang digunakan oleh Pratama (2014) dan variabel Kualitas Audit mengadopsi instrumen yang digunakan oleh Nugrahini (2015).

Populasi penelitian sebanyak 116 auditor Kantor Inspektorat Daerah di Propinsi Daerah Istimewa Yogyakarta. Metode pengumpulan data dalam penelitian ini adalah dengan menggunakan kuesioner. Jenis pertanyaan yang digunakan adalah pertanyaan tertutup. Data yang digunakan dalam penelitian ini adalah data primer.

Teknik analisis data dilakukan dengan statistik deskriptif, uji prasyarat analisis, uji regresi linier sederhana, dan uji regresi linier berganda. Statistik deskriptif meliputi rata-rata (mean), nilai tengah (median), standar deviasi (standard deviation), nilai minimum, nilai maksimum, rentang data (range) dan jumlah (sum). Uji prasyarat analisis terdiri dari uji linieritas, multikolinieritas, dan heteroskedastisitas. Uji regresi linier sederhana digunakan untuk mengetahui pengaruh Kompetensi Auditor terhadap
Kualitas Audit, pengaruh Independensi Auditor terhadap Kualitas Audit, pengaruh Moral Reasoning Auditor terhadap Kualitas Audit. Sedangkan uji regresi linier berganda digunakan untuk mengetahui pengaruh Kompetensi, Independensi dan Moral Reasoning Auditor secara bersama-sama (simultan) terhadap Kualitas Audit.

\section{HASIL PENELITIAN DAN}

PEMBAHASAN

Statistik Deskriptif

Tabel 1. Hasil Deskripsi Statistik Variabel

\begin{tabular}{|c|c|c|c|c|}
\hline Variabel & $\begin{array}{l}\text { Mi } \\
\text { n. }\end{array}$ & $\begin{array}{l}\text { Mak } \\
\text { s. }\end{array}$ & $\begin{array}{l}\text { Mea } \\
n\end{array}$ & $\begin{array}{l}\text { St. } \\
\text { Dev }\end{array}$ \\
\hline $\begin{array}{l}\text { Kualitas } \\
\text { Audit }\end{array}$ & 64 & 104 & $\begin{array}{l}82,1 \\
2\end{array}$ & $\begin{array}{l}8,36 \\
7\end{array}$ \\
\hline $\begin{array}{l}\text { Kompeten } \\
\text { si Auditor }\end{array}$ & 41 & 60 & $\begin{array}{l}47,8 \\
0\end{array}$ & $\begin{array}{l}4,71 \\
0\end{array}$ \\
\hline $\begin{array}{l}\text { Independe } \\
\text { nsi } \\
\text { Auditor }\end{array}$ & 28 & 44 & $\begin{array}{l}34,9 \\
3\end{array}$ & $\begin{array}{l}4,07 \\
4\end{array}$ \\
\hline $\begin{array}{l}\text { Moral } \\
\text { Reasoning } \\
\text { Auditor }\end{array}$ & 23 & 34 & $\begin{array}{l}27,9 \\
8\end{array}$ & $\begin{array}{l}2,21 \\
3\end{array}$ \\
\hline
\end{tabular}

Kualitas Audit memiliki skor tertinggi sebesar 104 dan skor terendah sebesar 64. Hal tersebut menunjukkan bahwa besar Kualitas Audit yang menjadi sampel penelitian ini berkisar antara 64 sampai 104 dengan nilai tengah 82,12 pada standar deviasi 8,367.

Kompetensi Auditor memiliki skor tertinggi sebesar 60 dan skor terendah sebesar 41. Hal tersebut menunjukkan bahwa besar Kompetensi Auditor yang menjadi sampel penelitian ini berkisar 
JURNAL NOMINAL / VOLUME VII NOMOR 1 / TAHUN 2018

antara 41 sampai 60 dengan nilai tengah 47,80 pada standar deviasi 4,710.

Independensi Auditor memiliki skor tertinggi sebesar 44 dan skor terendah sebesar 28. Hal tersebut menunjukkan bahwa besar Independensi Auditor yang menjadi sampel penelitian ini berkisar antara 28 sampai 44 dengan nilai tengah 34,93 pada standar deviasi 4,074.

Moral Reasoning Auditor memiliki skor tertinggi sebesar 36 dan skor terendah sebesar 23. Hal tersebut menunjukkan bahwa besar Moral Reasoning Auditor yang menjadi sampel penelitian ini berkisar antara 23 sampai 36 dengan nilai tengah 27,98 pada standar deviasi 2,212.

Hasil Pengujian Hipotesis dan Pembahasan

Uji Regresi Linier Sederhana

Analisis regresi linier sederhana digunakan untuk mengetahui pengaruh variabel independen secara individu (parsial) terhadap variabel dependen. Hasil uji regresi linier sederhana variable independen yang terdiri dari Kompetensi Auditor, Independensi Auditor, dan Moral Reasoning Auditor secara individu (parsial) terhadap Kualitas Audit.

H1. Terdapat pengaruh positif dan signifikan Kompetensi Auditor terhadap Kualitas Audit

Tabel 2. Hasil Uji Regresi Linier Sederhana Kompetensi Auditor

\begin{tabular}{llll}
\hline Variabel & $\begin{array}{l}\text { Koe. } \\
\text { Regre } \\
\text { si }\end{array}$ & $\begin{array}{l}\text { t } \\
\text { hitun } \\
\text { g }\end{array}$ & Sig. \\
\hline Konstanta & 22,785 & & \\
\hline Kompeten & 1,241 & 8,847 & $\begin{array}{l}0,00 \\
\text { si Auditor }\end{array}$ \\
\hline R: 0,699 & & & 0 \\
\hline$R^{2}: 0,488$ & & & \\
\hline
\end{tabular}

Berdasarkan hasil analisis regresi tersebut dapat diketahui persamaan regresi satu prediktor sebagai berikut:

$$
\mathrm{Y}=22,785+1,241 X_{1}
$$

Persamaan tersebut menunjukkan bahwa konstanta sebesar 22,785, hal ini menunjukkan bahwa apa bila variabel Kompetensi Auditor dianggap nol, maka variabel Kualitas Audit adalah sebesar 22,785 satuan. Koefisien regresi X1 sebesar 1,241 menunjukkan bahwa setiap kenaikan Kompetensi Auditor sebesar satu satuan maka akan menaikkan Kualitas Audit sebesar 1,241. Berdasarkan dari hasil tersebut menunjukkan bahwa arah model regresi ini adalah positif.

Berdasarkan hasil Tabel 2 diatas, menunjukkan nilai korelasi (r) bernilai positif sebesar 0,699 dan $R$ square $\left(R^{2}\right)$ yang dihasilkan yaitu sebesar 0,488 $(48,8 \%)$. Hal ini berarti variabel Kompetensi Auditor mempengaruhi Kualitas Audit sebesar $R^{2}$ yaitu sebesar $48,8 \%$, sedangkan sisanya $51,2 \%$ dipengaruhi oleh varibel lain diluar penelitian.

Berdasarkan hasil analisis data diperoleh nilai t hitung sebesar 8,847 lebih 


\section{JURNAL NOMINAL / VOLUME VII NOMOR 1 / TAHUN 2018}

besar dari t tabel sebesar 1,66388 sehingga memiliki pengaruh yang signifikan. Berdasarkan hasil pengujian yang telah dilakukan, diperoleh nilai signifikansi sebesar 0,000, yaitu lebih kecil dari level of significant sebesar $0,050(0,000<0,050)$. Koefisien regresi memiliki arah positif sebesar 1,241.

Hasil penelitian ini mendukung hipotesis pertama yang menyatakan bahwa "Terdapat pengaruh positif Kompetensi Auditor terhadap Kualitas Audit”. Hubungan antara Kompetensi Auditor terhadap Kualitas Audit ini adalah positif dan signifikan, yang ditunjukkan dengan nilai signifikansi kurang dari level of significant 0,050 atau $(0,000<0,050)$ dan nilai t hitung sebesar 8,847 lebih besar dari t tabel sebesar 1,66388. Koefisien regresi sebesar 1,241 yang memiliki arah positif yang berarti semakin tinggi Kompetensi Auditor maka Kualitas Audit juga semakin tinggi. Koefisien korelasi $r_{(x 1 y)}$ sebesar 0,699 , nilai koefisien determinasi $r^{2}{ }_{(x 1 y)}$ yaitu sebesar $0,488(48,8 \%)$ yang berarti Kompetensi Auditor berpengaruh secara positif terhadap Kualitas Audit sebesar $48,8 \%$ sedangkan sisanya $51,2 \%$ dipengaruhi oleh variabel lain di luar penelitian.

Hasil penelitian ini juga didukung oleh hasil penelitian yang dilakukan oleh Nugrahini (2015), dimana hasil penelitian yang dilakukan membuktikan bahwa adanya pengaruh positif Kompetensi Auditor terhadap Kualitas Audit. Dimana variabel Kompetensi Auditor memiliki tingkat signifikansi sebesar 0,000 , hasil ini lebih kecil dari level of significant yaitu $0,050(0,000<0,050)$. Kemudian penelitian yang dilakukan oleh Dewi (2016) juga membuktikan adanya pengaruh positif Kompetensi Auditor terhadap Kualitas Audit. Dimana variabel Kompetensi Auditor memiliki tingkat signifikansi 0,034, hasil ini lebih kecil dari level of significant $0,050(0,034<0,050)$. Hal ini berarti bahwa semakin meningkat Kompetensi Auditor, maka Kualitas Audit juga akan semakin meningkat.

H2. Terdapat pengaruh positif dan signifikan Independensi Auditor terhadap Kualitas Audit

Tabel 3. Hasil Uji Regresi Linier Sederhana Independensi Auditor

\begin{tabular}{llll}
\hline Variabel & $\begin{array}{l}\text { Koe. } \\
\text { Regre } \\
\text { si }\end{array}$ & $\begin{array}{l}\mathbf{t} \\
\text { hitun } \\
\mathbf{g}\end{array}$ & Sig. \\
\hline Konstanta & 46,730 & & \\
\hline Kompeten & 1,013 & 5,135 & 0,00 \\
si Auditor & & & 0 \\
\hline R: 0,493 & & & \\
\hline$R^{2}: 0,243$ & & & \\
\hline
\end{tabular}

Berdasarkan hasil analisis regresi tersebut dapat diketahui persamaan regresi satu prediktor sebagai berikut:

$$
\mathrm{Y}=46,730+1,013 X_{2}
$$

Persamaan tersebut menunjukkan bahwa konstanta sebesar 46,730, hal ini menunjukkan bahwa apa bila variabel Independensi Auditor dianggap nol, maka 


\section{JURNAL NOMINAL / VOLUME VII NOMOR 1 / TAHUN 2018}

variabel Kualitas Audit adalah sebesar 46,730 satuan. Koefisien regresi X2 sebesar 1,013 menunjukkan bahwa setiap kenaikan Independensi Auditor sebesar satu satuan maka akan menaikkan Kualitas Audit sebesar 1,013. Berdasarkan dari hasil tersebut menunjukkan baahwa arah model regresi ini adalah positif.

Berdasarkan hasil Tabel 3 diatas, menunjukkan nilai korelasi (r) bernilai positif sebesar 0,493 dan $R$ square $\left(R^{2}\right)$ yang dihasilkan yaitu sebesar 0,243 $(24,3 \%)$. Hal ini berarti variabel Independensi Auditor mempengaruhi Kualitas Audit sebesar $R^{2}$ yaitu sebesar $24,3 \%$, sedangkan sisanya $75,7 \%$ dipengaruhi oleh varibel lain diluar penelitian.

Berdasarkan hasil analisis data diperoleh nilai t hitung sebesar 5,135 lebih besar dari t tabel sebesar 1,66388 sehingga memiliki pengaruh yang signifikan. Berdasarkan hasil pengujian yang telah dilakukan, diperoleh nilai signifikansi sebesar 0,000, yaitu lebih kecil dari level of significant sebesar 0,050 $(0,000<0,050)$. Koefisien regresi memiliki arah positif sebesar 1,013 .

Hasil penelitian ini mendukung hipotesis kedua yang menyatakan bahwa “Terdapat pengaruh positif Independensi Auditor terhadap Kualitas Audit”. Hubungan antara Independensi Auditor terhadap Kualitas Audit ini adalah positif dan signifikan, yang ditunjukkan dengan nilai signifikansi kurang dari level of significant 0,050 atau $(0,000<0,050)$ dan nilai t hitung sebesar 5,135 lebih besar dari t tabel sebesar 1,66388. Koefisien regresi sebesar 1,013 yang memiliki arah positif yang berarti semakin tinggi Independensi Auditor maka Kualitas Audit juga semakin tinggi. Koefisien korelasi $r_{(x 2 y)}$ sebesar 0,493 , nilai koefisien determinasi $r^{2}{ }_{(x 2 y)}$ yaitu sebesar $0,243(24,3 \%)$ yang berarti Independensi Auditor berpengaruh secara posi tif terhadap Kualitas Audit sebesar $24,3 \%$ sedangkan sisanya $75,7 \%$ dipengaruhi oleh variabel lain di luar penelitian.

Hasil penelitian ini juga didukung oleh hasil penelitian yang dilakukan oleh Harahap (2015), dimana hasil penelitian yang dilakukan membuktikan bahwa adanya pengaruh positif Independensi Auditor terhadap Kualitas Audit. Dimana variabel Independensi Auditor memiliki tingkat signifikansi sebesar 0,035, hasil ini lebih kecil dari level of significant yaitu $0,050(0,035<0,050)$. Selain itu, penelitian yang dilakukan oleh Pratiwi (2014) juga membuktikan adanya pengaruh positif Independensi Auditor terhadap Kualitas Audit. Dimana variabel Independensi Auditor memiliki tingkat signifikansi 0,000, hasil ini lebih kecil dari level of significant yaitu $0,050(0,000<0,050)$. Hal ini berarti bahwa semakin meningkat Independensi 


\section{JURNAL NOMINAL / VOLUME VII NOMOR 1 / TAHUN 2018}

Auditor, maka Kualitas Audit juga akan semakin meningkat.

\section{H3. Terdapat pengaruh positif dan} signifikan Moral Reasoning Auditor terhadap Kualitas Audit

Tabel 4. Hasil Uji Regresi Linier Sederhana Moral Reasoning Auditor

\begin{tabular}{llll}
\hline Variabel & $\begin{array}{l}\text { Koe. } \\
\text { Regre } \\
\text { si }\end{array}$ & $\begin{array}{l}\text { t } \\
\text { hitun } \\
\text { g }\end{array}$ & Sig. \\
\hline Konstanta & 58,396 & & \\
\hline $\begin{array}{l}\text { Kompeten } \\
\text { si Auditor }\end{array}$ & 0,848 & 2,083 & 0,04 \\
\hline R: 0,224 & & & 0 \\
\hline$R^{2}: 0,050$ & & & \\
\hline
\end{tabular}

Berdasarkan hasil analisis regresi tersebut dapat diketahui persamaan regresi satu prediktor sebagai berikut:

$$
\mathrm{Y}=58,396+0,848 X_{3}
$$

Persamaan tersebut menunjukkan bahwa konstanta sebesar 58,396, hal ini menunjukkan bahwa apa bila variabel Moral Reasoning Auditor dianggap nol, maka variabel Kualitas Audit adalah sebesar 58,396 satuan. Koefisien regresi X3 sebesar 0,848 menunjukkan bahwa setiap kenaikan Moral Reasoning Auditor sebesar satu satuan maka akan menaikkan Kualitas Audit sebesar 0,848. Berdasarkan dari hasil tersebut menunjukkan bahwa arah model regresi ini adalah positif.

Berdasarkan hasil Tabel 4 diatas, menunjukkan nilai korelasi (r) bernilai positif sebesar 0,224 dan $R$ square $\left(R^{2}\right)$ yang dihasilkan yaitu sebesar 0,050 (5\%). Hal ini berarti variabel Moral Reasoning
Auditor mempengaruhi Kualitas Audit sebesar $R^{2}$ yaitu sebesar 5\%, sedanngkan sisanya 95\% dipengaruhi oleh varibel lain diluar penelitian.

Berdasarkan hasil analisis data diperoleh nilai t hitung sebesar 2,083 lebih besar dari t tabel sebesar 1,66388 sehingga memiliki pengaruh yang signifikan. Berdasarkan hasil pengujian yang telah dilakukan, diperoleh nilai signifikansi sebesar 0,040, yaitu lebih kecil dari level of significant sebesar 0,050 $(0,040<0,050)$. Koefisien regresi memiliki arah positif sebesar 0,848 .

Hasil penelitian ini mendukung hipotesis ketiga yang menyatakan bahwa "Terdapat pengaruh positif antara Moral Reasoning Auditor terhadap Kualitas Audit". Hubungan antara Moral Reasoning Auditor terhadap Kualitas Audit ini adalah positif dan signifikan, yang ditunjukkan dengan nilai signifikansi kurang dari level of significant 0,050 atau $(0,040<0,050)$ dan nilai t hitung sebesar 2,083 lebih besar dari t tabel sebesar 1,66388. Koefisien regresi sebesar 0,848 yang memiliki arah positif yang berarti semakin tinggi Moral Reasoning Auditor maka Kualitas Audit juga semakin tinggi. Koefisien korelasi $r_{(x 3 y)}$ sebesar 0,224 , nilai koefisien determinasi $r_{(x 3 y)}^{2}$ yaitu sebesar 0,050 (5\%) yang berarti Moral Reasoning Auditor berpengaruh secara positif terhadap Kualitas Audit sebesar 5\% sedangkan 


\section{JURNAL NOMINAL / VOLUME VII NOMOR 1 / TAHUN 2018}

sisanya 95\% dipengaruhi oleh variabel lain di luar penelitian.

Hasil penelitian ini juga didukung oleh hasil penelitian yang dilakukan oleh Pratama (2014), dimana hasil penelitian yang dilakukan membuktikan bahwa adanya pengaruh positif Moral Reasoning Auditor terhadap Kualitas Audit. Dimana variabel Moral Reasoning Auditor memiliki tingkat signifikansi sebesar 0,001, hasil ini lebih kecil dari level of significant yaitu $0,050 \quad(0,001<0,050) . \quad$ Kemudian penelitian yang dilakukan oleh Sulistyaningsih (2015) menyimpulkan adanya pengaruh positif Moral Reasoning terhadap Kualitas Audit, dimana variabel Moral Reasoning memiliki tingkat signifikansi 0,026. Hasil ini lebih kecil dari level of significant yaitu 0,050. Hal ini berarti bahwa semakin meningkat Moral Reasoning Auditor, maka Kualitas Audit juga akan semakin meningkat.

\section{Uji Regresi Linier Berganda}

H4. Terdapat pengaruh positif dan signifikan Kompetensi, Independensi dan Moral Reasoning Auditor secara bersama-sama terhadap Kualitas Audit

Tabel 5. Hasil Uji Regresi Linier Berganda

\begin{tabular}{ll}
\hline \multicolumn{1}{c}{ Variable } & $\begin{array}{c}\text { Koefisien } \\
\text { Regresi }\end{array}$ \\
\hline Konstanta & 13,920 \\
\hline Kompetensi Auditor & 1,204 \\
\hline Independensi Auditor & 0,008 \\
\hline $\begin{array}{l}\text { Moral Reasoning } \\
\text { Auditor }\end{array}$ & 0,370 \\
\hline $\mathrm{R}$ & 0,705 \\
\hline
\end{tabular}

\begin{tabular}{ll}
\hline$R^{2}$ & 0,498 \\
\hline Adjusted $R^{2}$ & 0,479 \\
\hline F hitung & 26,410 \\
\hline Sig. F & 0,000 \\
\hline
\end{tabular}

Berdasarkan hasil analisis regresi tersebut dapat diketahui persamaan regresi satu prediktor sebagai berikut:

$$
\begin{aligned}
\mathrm{Y}= & 13,920+1,204 X_{1}+0,008 X_{2}+ \\
& 0,370 X_{3}
\end{aligned}
$$

Persamaan tersebut menunjukkan bahwa konstanta sebesar 13,920, hal ini menunjukkan bahwa apa bila variabel Kompetensi, Independensi dan Moral Reasoning Auditor dianggap nol, maka variabel Kualitas Audit adalah sebesar 13,920 satuan. Koefisien regresi X4, yaitu variabel Kompetensi Auditor memberikan nilai koefisien 1,204 yang berarti jika Kompetensi Auditor meningkat satu satuan maka Kualitas Audit akan meningkat sebesar 1,204 satuan dengan asumsi X2 dan X3 tetap, variabel Independensi Auditor memberikan nilai koefisien 0,008 yang berarti jika Independensi Auditor meningkat satu satuan maka Kualitas Audit akan meningkat sebesar 0,008 satuan dengan asumsi $\mathrm{X} 1$ dan $\mathrm{X} 3$ tetap, variabel Moral Reasoning Auditor memberikan nilai koefisien 0,370 yang berarti jika Moral Reasoning Auditor meningkat satu satuan maka Kualitas Audit akan meningkat sebesar 0,370 satuan dengan asumsi X1 dan X2 tetap. Berdasarkan dari hasil tersebut 


\section{JURNAL NOMINAL / VOLUME VII NOMOR 1 / TAHUN 2018}

menunjukkan bahwa arah model regresi ini adalah positif.

Berdasarkan hasil Tabel 5 diatas, menunjukkan nilai korelasi (r) bernilai positif sebesar 0,705 dan adjusted $R$ square yang dihasilkan yaitu sebesar 0,479 $(47,9 \%)$. Hal ini berarti variabel Kompetensi, Independensi dan Moral Reasoning Auditor mempengaruhi Kualitas Audit sebesar adjusted $R$ square yaitu sebesar $47,9 \%$, sedangkan sisanya $52,1 \%$ dipengaruhi oleh varibel lain diluar penelitian.

Berdasarkan hasil analisis data diperoleh nilai $\mathrm{F}$ hitung sebesar 26,410 lebih besar dari $F$ tabel sebesar 2,72 sehingga memiliki pengaruh yang signifikan dan signifikansi sebesar 0,000 yang berarti lebih kecil dari level of significant yaitu $0,050(0,000<0,050)$.

Hasil penelitian ini mendukung hipotesis keempat yang menyatakan bahwa "Terdapat pengaruh positif Kompetensi, Independensi dan Moral Reasoning Auditor secara bersama-sama terhadap Kualitas Audit". Hubungan antara Kompetensi, Independensi dan Moral Reasoning Auditor secara bersama-sama terhadap Kualitas Audit adalah positif dan signifikan, yang ditunjukkan dengan nilai signifikansi kurang dari level of significant 0,050 atau $(0,000<0,050)$ dan nilai $\mathrm{F}$ hitung sebesar 26,410 lebih besar dari F tabel sebesar 2,72. Hal ini ditunjukkan oleh nilai koefisien regresi X1 sebesar 1,204 yang berarti apabila Kompetensi Auditor meningkat satu satuan maka Kualitas Audit akan naik sebesar 1,204 satuan dengan asumsi X2 dan X3 tetap. Niilai koefisien regresi X2 sebesar 0,008 yang berarti apabila Independensi Auditor meningkat satu satuan maka Kualitas Audit akan naik sebesar 0,008 satuan dengan asumsi X1 dan X3 tetap. Nilai koefisien regresi X3 sebesar 0,370 yang berarti apabila Moral Reasoning Auditor meningkat satu satuan maka Kualitas Audit akan naik sebesar 0,370 satuan dengan asumsi X1 dan X2 tetap. Hal ini juga dapat dilihat dari nilai korelasi regresi (r) yang bernilai positif sebesar 0,705. Dari hasil penelitian diperoleh nilai adjusted $\mathrm{R}$ square sebesar 0,479 yang berarti Kompetensi, Independensi dan Moral Reasoning Auditor secara bersamasama mempengaruhi Kualitas Audit sebesar $47,9 \%$ sedangkan sisanya $52,1 \%$ dipengaruhi oleh variabel lain di luar penelitian.

Hasil penelitian ini juga didukung oleh hasil penelitian yang dilakukan oleh Nugrahini (2015), hasil penelitian tersebut menyimpulkan bahwa Kompetensi Auditor berpengaruh positif terhadap Kualitas Audit. Kemudian penelitian yang dilakukan oleh Harahap (2015), hasilnya menyimpulkan bahwa Independensi Auditor berpengaruh positif terhadap Kualitas Audit. Pratama (2014) dimana hasil penelitiannya menyimpulkan bahwa Moral Reasoning Auditor berpengaruh 


\section{JURNAL NOMINAL / VOLUME VII NOMOR 1 / TAHUN 2018}

positif terhadap Kualitas Audit. Hasil penelitian ini mengindikasikan bahwa terdapat pengaruh positif dan signifika Kompetensi, Independensi dan Moral Reasoning Auditor secara bersama-sama terhadap Kualitas Audit. Sehingga jika seseorang memiliki Kompetensi, Independensi dan Moral Reasoning Auditor yang tinggi maka akan semakin baik Kualitas Audit.

\section{SIMPULAN DAN SARAN}

Berdasarkan hasil penelitian, maka dapat diambil empat kesimpulan, yaitu:

1. Kompetensi Auditor berpengaruh positif dan signifikan terhadap Kualitas Audit yang ditunjukkan dengan nilai signifikansi kurang dari level of significant yaitu 0,050 atau $(0,000<$ $0,050)$ dan nilai t hitung sebesar 8,847 lebih besar dari t tabel sebesar 1,66388. Hal ini menunjukkan bahwa pengaruh Kompetensi Auditor terhadap Kualitas Audit bersifat positif dan signifikan, dengan demikian semakin tinggi Kompetensi Auditor maka akan semakin tinggi pula Kualitas Audit.

2. Independensi Auditor berpengaruh positif dan signifikan terhadap Kualitas Audit yang ditunjukkan dengan nilai signifikansi kurang dari level of significant yaitu 0,050 atau $(0,000<$ $0,050)$ dan nilai t hitung sebesar 5,135 lebih besar dari t tabel sebesar 1,66388. Hal ini menunjukkan bahwa pengaruh
Independensi Auditor terhadap Kualitas Audit bersifat positif dan signifikan, dengan demikian semakin tinggi Independensi Auditor maka akan semakin tinggi pula Kualitas Audit.

3. Moral Reasoning Auditor berpengaruh positif dan signifikan terhadap Kualitas Audit yang ditunjukkan dengan nilai signifikansi kurang dari level of significant yaitu 0,050 atau $(0,040<$ 0,050) dan nilai t hitung sebesar 2,083 lebih besar dari t tabel sebesar 1,66388. Hal ini menunjukkan bahwa pengaruh Moral Reasoning Auditor terhadap Kualitas Audit bersifat positif dan signifikan, dengan demikian semakin tinggi Moral Reasoning Auditor maka akan semakin tinggi pula Kualitas Audit.

4. Kompetensi, Independensi dan Moral Reasoning Auditor secara bersama-sama (simultan) memberikan pengaruh positif dan signifikan terhadap Kualitas Audit.

Berdasarkan hasil penelitian, maka dapat diambil tujuh saran, yaitu

1. Berdasarkan data hasil penelitian, skor terendah pada variabel Kualitas Audit yaitu pada pernyataan hasil audit intern harus dikomunikasikan secara lisan, sebaiknya perlu adanya komunikasi secara lisan dari auditor tentang hasil audit agar hasilnya dapat dipahami.

2. Berdasarkan data hasil penelitian, skor terendah pada variabel Kompetensi Auditor yaitu pada pernyataan auditor 


\section{JURNAL NOMINAL / VOLUME VII NOMOR 1 / TAHUN 2018}

harus memahami ilmu statistik, sebaiknya auditor mampu memahami ilmu statistik agar kemungkinankemungkinan yang terjadi dapat dilaporkan dalam hasil audit sehingga kualitas audit semakin baik. Penelitian selanjutnya disarankan untuk memperhatikan aspek timelag antara data setelah laporan keuangan dipublikasikan terhadap reaksi harga saham perusahaan.

3. Berdasarkan data hasil penelitian, skor terendah pada variabel Independensi Auditor yaitu pada pernyataan pemeriksa mendapat kerja sama yang aktif dari karyawan manajerial selama pemeriksaan, sebaiknya perlu adanya kerja sama dari berbagai pihak agar kualitas audit menjadi lebih baik.

4. Berdasarkan data hasil penelitian, skor terendah pada variabel Moral Reasoning Auditor yaitu pada pernyataan mengikuti perintah atasan merupakan tindakan yang wajar, sebaiknya perintah yang diberikan kepada auditor tidak terlepas dari aturan yang ada sehingga auditor mampu menghasilkan kualitas audit yang baik.

5. Bagi peneliti selanjutnnya sebaiknya dilakukan pada saat auditor tidak memiliki banyak pekerjaan audit sehingga lebih banyak mendapat responden.
6. Penelitian selanjutnya diharapkan dapat dilakukan di daerah lain selain Yogyakarta.

7. Pada penelitian selanjutnya diharapkan peneliti dapat menambah metode lain dalam penelitiannya sehingga data yan $g$ diperoleh dapat sesuai dengan keadaan yang sebenarnya, misalnya menambahkan metode wawancara.

\section{DAFTAR PUSTAKA}

Angga, D. (2017). Inspektorat Daerah Bakal Ditarik Pusat. www.koransindo.com (diakses 27 Maret 2017).

Bastian, I. (2014). Audit Sektor Publik. Edisi Ke-3. Jakarta: Salemba Empat.

Dewi, A. C. (2016). Pengaruh Pengalaman Kerja, Kompentensi dan Independensi terhadap Kualitas Audit dengan Etika Sebagai Variabel Moderasi. Skripsi. Universitas Negeri Yogyakarta.

Ferdinan. (2010). KPK Tetapkan Auditor BPK Jadi Tersangka. www.okezone.com (diakses 26 Maret 2017).

Gaffikin, M. \& Lindawati, ASL. (2012). The Moral Reasoning of Publik Accountants in the Development of a Code of Ethics: the Case of Indonesia. Australasian Accounting, Business and Finance Journal, 6, 328.

Harahap, L. (2015). Pengaruh Kompetensi, Independensi, Objektivitas dan Sensivitas Etika Profesi terhadap Kualitas Hasil Audit. Skripsi. Universitas Negeri Yogyakarta. 
Indrianto, N., \& Bambang, S. (2002). Metodologi Penelitian Bisnis: untuk Akuntansi \& Manajemen. Yogyakarta: BPFE.

Jusup, Al. H. (2014). Auditing. Yogyakarta: Bagian Penerbitan Sekolah Tinggi Ilmu Ekonomi YKPN.

Munawir, H.S. (1999). Auditing Modern. Yogyakarta:

BPFEYOGYAKARTA.

Nabhani, A. (2009). 72 LKPD Disclaimer, 556 Kasus Rugikan Rp $301 \mathrm{M}$. www.okezone.com (diakses 27 Maret 2017).

Nugrahini, P. (2015). Pengaruh Kompetensi dan Profesionalisme Auditor Internal terhadap Kualitas Audit, (Online). Skripsi. Universitas Negeri Yogyakarta.

Peraturan Pemerintah No. 60 Tahun 2008 tentang Sistem Pengendalian Intern Pemerintah.

Prasetiyo, B. (2016). Ini Daftar Peringkat Korupsi Dunia, Indonesia Urutan Berapa. www.m.tempo.co (diakses 25 Maret 2017).

Pratama, N. A. (2014). Pengaruh Moral Reasoning dan Due Professional Care terhadap Kualitas Audit Di Lingkungan Pemerintah Daerah. Skripsi. Universitas Negeri Yogyakarta.

Pratiwi, A. (2014). Pengaruh Inddependensi dan Akuntabilitas Auditor terhadap Kualitas Audit. Skripsi. Universitas Negeri Yogyakarta.

Sugiyono. (2011). Metode Penelitian Kuantitatif Kualitatif dan $R \& D$. Bandung: Alfabeta.
Sulistyningsih, S. H. (2015). Pengaruh Skeptisisme Profesional Auditor, Pengalaman Kerja Auditor dan Moral Reasoning terhadap Kualitas Audit. Skripsi. Universitas Negeri Yogyakarta.

Ulum MD, I. (2012). Audit Sektor Publik. Jakarta: PT. Bumi Aksara. 